\title{
Wyrok Trybunału Konstytucyjnego w sprawie stanu wojennego w 30-lecie jego wprowadzenia
}

W maju 2011 r. odbyła się konferencja zatytułowana $W$ trzydziestolecie encykliki „Laborem exercens" . Dokładnie 30 lat minęło od ogłoszenia przez Jana Pawła II encykliki Laborem exercens wpisującej się w poczet encyklik socjalnych. Jan Paweł II odniósł się w niej do pracy ludzkiej i sytuacji ludzi pracujących, nie tylko w wymiarze chrześcijańskim, kulturowym, lecz także w wymiarze społecznym. W tym samym okresie wprowadzono w Polsce stan wojenny, który rzuca cień przede wszystkim na prawa wolnościowe i obywatelskie wszystkich Polaków, nawet tych nieuczestniczących aktywnie w działalności opozycyjnej. Okres stanu wojennego wywarł również duży wpływ na ówczesne stosunki pracy. Zniesiono m.in. legalną działalność dopiero co powstałych niezależnych organizacji zawodowych i społecznych. Zważywszy na wyrok Trybunału Konstytucyjnego z dnia 16 marca 2011 r. w sprawie dekretów stanu wojennego, warto przypomnieć wpływ aktów stanu wojennego na stosunki zatrudnienia i zabezpieczenia społecznego, zwłaszcza, że nigdy nie dokonano pełnego zadośćuczynienia krzywdom, które zostały spowodowane stanem wojennym również w stosunkach pracy.

" Dr Katarzyna Roszewska, Katedra Prawa Pracy, Wydział Prawa i Administracji, Uniwersytet Kardynała Stefana Wyszyńskiego, 01-938 Warszawa, ul. Wóycickiego 1/3.

1 Tekst został oddany do druku przed uchwaleniem zmian w ustawie o emeryturach i rentach z Funduszu Ubezpieczeń Społecznych, Dz. U. 2013, poz. 1440, tekst jedn. ze zm., zwanej dalej ustawą o emeryturach i rentach z FUS w zakresie traktowania okresu niewykonywania pracy na skutek represji politycznych przed 4 czerwca 1989 r., co wymagać będzie nowego spojrzenia na kwestię rekompensaty $\mathrm{w}$ dziedzinie zabezpieczenia społecznego faktu pozostawania bez pracy na skutek represji. Autorka zwraca uwagę na tę zmianę zatem w zakresie możliwym na etapie korekty. 
Dekret o stanie wojennym z dnia 12 grudnia $1981 r^{2}$ - jak wskazywała preambuła - został wprowadzony w celu zapewnienia wzmożonej ochrony podstawowych interesów państwa i obywateli, w celu stworzenia warunków skutecznej ochrony suwerenności i niepodległości PRL oraz spokoju, ładu i porządku publicznego ze względu na konieczność zapewnienia sprawnego funkcjonowania władzy i administracji państwowej oraz gospodarki narodowej w czasie obowiązywania stanu wojennego. Przewidywał m.in. ograniczenia dotyczące obywateli w zakresie możliwości internowania, swobody poruszania się osób („godzina milicyjna”), zwoływania i odbywania zgromadzeń, publicznych imprez artystycznych, rozrywkowych i sportowych oraz zbiórek publicznych (tylko za uprzednim zezwoleniem). Ograniczenia tego nie stosowało się do nabożeństw i obrzędów religijnych, kościołów i związków wyznaniowych oraz zbiórek na cele religijne. Dekret przewidywał możliwość dokonywania wywłaszczeń nieruchomości, zajęcia środków transportu, mienia obywateli położonego w granicach PRL, również w stosunku do cudzoziemców i ich mienia. Istniała możliwość nałożenia obowiązkowych dostaw na rolników, przydziału mieszkań i kwaterunku do rodzin z nadwyżką powierzchni mieszkaniowej, wprowadzenia zakazu bądź ograniczenia ruchu pojazdów, przewozów osób i rzeczy w transporcie drogowym, kolejowym, lotniczym i wodnym, ograniczenia lotów polskich i obcych statków powietrznych, ruchu granicznego osób i towarów, powoływania specjalnych komisarzy do kierowania wykonywaniem przez spółdzielnie i ich związki statutowych zadań gospodarczych i społeczno-kulturalnych. Rozpowszechnianie publikacji i widowisk wymagało uprzedniego uzyskania zezwolenia. Istniał zakaz wytwarzania pieczątek i stempli przez osoby fizyczne, stowarzyszenia, zrzeszenia, związki zawodowe, organizacje społeczne i zawodowe, a przez podmioty państwowe i spółdzielcze - za odpowiednim zezwoleniem. Obowiązywała cenzura przesyłek pocztowych i korespondencji telekomunikacyjnej oraz kontrola rozmów telefonicznych, konieczność złożenia do depozytu odbiorników radiowych, broni myśliwskiej, sportowej.

Dekret zawierał osobny szeroki katalog ograniczeń w sferze prawnopracowniczej. Na gruncie zbiorowych uprawnień pracowniczych dekret stanowił, że zawiesza się prawo do strajków i akcji protestacyjnych. Udział w strajku stanowił ciężkie naruszenie przez pracownika podstawowych obowiązków pracowniczych, a organizowanie lub kierowanie strajkiem lub akcją protestacyjną mogło być uznane za spowodowanie poważnego zakłócenia w funkcjonowaniu gospodarki narodowej. Przewidywał możliwość zawieszenia działalności związkowej lub społecznej, jeżeli działalność stowarzyszenia, związku zawodowego, zrzeszenia albo organizacji społecznej lub zawodowej miałaby godzić w ustrój polityczny i społeczny lub w porządek prawny PRL albo w inny sposób zagrażała interesom bezpieczeństwa lub obronności państwa. Działalność taka mogła być zawieszona także z innych ważnych przyczyn. Co istotne, organy zawieszające działalność

\footnotetext{
2 Dz. U. nr 29, poz. 154.
} 
np. związku zawodowego określały jednocześnie sposób postępowania z jego majątkiem ${ }^{3}$. Zawieszona została również działalność samorządu załóg przedsiębiorstw (zakładów) państwowych w zakresie określonym przez Radę Ministrów w drodze rozporządzenia ${ }^{4}$.

Dekret wprowadzał istotne modyfikacje w zakresie indywidualnego prawa pracy. Przewidywał możliwość wprowadzenia przez Radę Ministrów (RM) powszechnego obowiązku wykonywania pracy w czasie stanu wojennego. Rada Ministrów, w drodze rozporządzenia, określała zasady stosowania przepisów dotyczących stosunków pracy oraz kategorie osób nie podlegających powszechnemu obowiązkowi wykonywania pracy, a także mogła wydawać przepisy normujące stosunek pracy, świadczenia z ubezpieczenia społecznego oraz działalność socjalno-bytową zakładów pracy na rzecz pracowników w sposób odmienny od przepisów prawa pracy 5 . W prawie do urlopu wypoczynkowego dekret stanowił, że pracownikowi przysługuje prawo do płatnego urlopu wypoczynkowego w wymiarze 1 dnia za każdy przepracowany miesiąc. Młodocianym oraz pracownikom zatrudnionym przy pracach szczególnie uciążliwych lub w warunkach szkodliwych dla zdrowia przysługiwał 1 dzień płatnego urlopu dodatkowego za każde przepracowane 3 miesiące. Pracownikowi, który wykonywał pracę w przedłużonym wymiarze czasu pracy przysługiwał 1 dzień płatnego urlopu dodatkowego za każdy miesiąc przepracowany w przedłużonym wymiarze czasu pracy. Zawieszeniu uległo udzielanie urlopów bezpłatnych i zwolnień okolicznościowych.

Dekret przewidywał również sankcje karne w takich wypadkach, jak niezgłoszenie się w oznaczonym terminie i miejscu celem uzyskania skierowania do uspołecznionego zakładu pracy albo niepodjęcie pracy zgodnie z wydanym skierowaniem, uchylanie się bez usprawiedliwionej przyczyny od wykonywania pracy określonej przez nawiązany stosunek pracy i przepisy prawa pracy, od wykonywania przydzielonych czynności lub powierzonej pracy albo odmowa nakazanego przeniesienia się do innego zakładu pracy.

Począwszy od 1989 r. wydano kilka ustaw rekompensujących skutki dekretów. Teoretycznych opracowań doczekał się m.in. akt prawny dokonujący w pewnym zakresie restytucji praw pracowniczych. Analizy ustawy o przywróceniu praw pracowniczych osobom pozbawionym zatrudnienia za działalność związkową,

${ }^{3}$ Zarządzenie nr 51 Prezesa Rady Ministrów z dnia 13 grudnia 1981 r. w sprawie zawieszenia działalności związków zawodowych i niektórych organizacji społecznych na czas obowiązywania stanu wojennego, „Monitor Polski”, nr 30, poz. 273.

${ }_{4}^{4}$ Rozporządzenie Rady Ministrów z dnia 30 grudnia 1981 r. w sprawie zawieszenia działalności samorządu załóg przedsiębiorstw państwowych na czas obowiązywania stanu wojennego, Dz. U. nr 32, poz. 185.

${ }^{5}$ Rozporządzenie RM z dnia 30 grudnia 1981 r. w sprawie wprowadzenia powszechnego obowiązku wykonywania pracy w czasie obowiązywania stanu wojennego, Dz. U. nr 32, poz. 187. Ponadto wydano rozporządzenie RM z dnia 18 grudnia 1981 r. w sprawie czasu pracy i zasad wprowadzania w uspołecznionych zakładach pracy dodatkowych dni wolnych od pracy w 1982 r., Dz. U. nr 31, poz. 176. 
samorządową, przekonania polityczne i religijne ${ }^{6}$ (ustawa o przywróceniu praw pracowniczych) podjęła się M. Gersdorf ${ }^{7}$. Ustawa ta jednak nie reguluje całościowo spraw związanych z naruszaniem praw pracowniczych w tamtym okresie ${ }^{8}$. Z kolei kwestię zaliczania okresu pozostawania bez pracy m.in. z powodów politycznych do okresu ubezpieczeniowego omawiała T. Liszcz ${ }^{9}$. Z zaliczaniem tego okresu do okresu ubezpieczeniowego wiązały się wątpliwości, pojawiające się po kolejnych regulacjach dotykających tego zagadnienia. Przepisy te budziły zastrzeżenia z punktu widzenia zgodności rozwiązań przyjętych w ustawie z 17 października 1991 r. o rewaloryzacji emerytur i rent, o zasadach ustalania emerytur i rent oraz o zmianie niektórych ustaw ${ }^{10}$ (ustawie rewaloryzacyjnej) oraz w ustawie o emeryturach i rentach z FUS z pierwotnym celem rozwiązania przyjętego w art. 11 ust. 2 ustawy o przywróceniu praw pracowniczych ${ }^{11}$.

Podkreślić również należy, że przez ponad 30 lat po wprowadzeniu stanu wojennego i ponad 20 lat od Okrągłego Stołu nie udało się wypracować regulacji, która kompleksowo ukształtowałaby skutki prawne stanu wojennego, mimo że ustawodawca wprowadził na przestrzeni lat wiele aktów prawnych dotyczących restytucji praw naruszonych dekretami stanu wojennego. Trybunał Konstytucyjny w uzasadnieniu wyroku z 16 marca 2011 r. ${ }^{12}$ wskazał przede wszystkim na ustawę z dnia 7 grudnia 1989 r. o zmianie ustawy o szczególnych uprawnieniach niektórych osób do ponownego nawiązania stosunku pracy ${ }^{13}$, ustawę z dnia 24 maja 1990 r. o zmianie niektórych przepisów o zaopatrzeniu emerytalnym ${ }^{14}$, ustawę z dnia 25 października 1990 r. o zwrocie majątku utraconego przez związki zawodowe i organizacje społeczne w wyniku wprowadzenia stanu wojennego ${ }^{15}$, ustawę z dnia 23 lutego 1991 r. o uznaniu za nieważne orzeczeń wydanych wobec

6 Ustawa z 24 maja 1989 r. o przywróceniu praw pracowniczych osobom pozbawionym zatrudnienia za działalność związkową, samorządową, przekonania polityczne I religijne, Dz. U. nr 32, poz.172, ze zm.

7 M. Gersdorf-Giaro, Ponowne nawiązanie stosunku pracy w trybie wyjątkowym, „Studia luridica" 1992, T. XXIII, s. 35 i n.

8 Mimo że ustawa obok prawa przywrócenia do pracy przewidywała w art. 11 skutki w zakresie ustalania uprawnień i świadczeń również dla osób, które nie skorzystały z prawa do ponownego nawiązania stosunku pracy nie określała roszczeń majątkowych.

9 T. Lıszcz, Zaliczanie do okresu ubezpieczenia emerytalno-rentowego czasu pozostawania bez pracy z powodów politycznych, PiZS 1996, nr 6, s. 57. Autorka obok art. 11 ust. 2 ustawy o przywróceniu praw pracowniczych wskazała posiłkowo na art. 2 ust. 2 pkt. 6 ustawy rewaloryzacyjnej, podkreślając jednak różnice między obiema podstawami - s. 59.

10 Dz. U. Nr 104, poz. 450, ze zm.

11 Choćby z tego względu, że w momencie wejścia w życie ustawy o przywróceniu praw pracowniczych nie obowiązywała jeszcze ustawa rewaloryzacyjna, która wprowadziła podział okresów uwzględnianych w stażu ubezpieczeniowym na okresy składkowe i nieskładkowe. Zaś art. 2 ust. 2 pkt. 6 ustawy rewaloryzacyjnej, a już w szczególności art. 7 ust. 4 ustawy o emeryturach i rentach z FUS nie realizowały pierwotnego, restytucyjnego celu ustawodawcy.

12 K 35/08, OTK-A 2011/2/10, Dz. U. 2011, nr 64, poz. 342.

13 Dz. U. nr 64, poz. 391.

14 Dz. U. nr 36, poz. 206, ze zm.

15 Dz. U. 1996, nr 143, poz. 661, ze zm. 
osób represjonowanych za działalność na rzecz niepodległego bytu Państwa Polskiego ${ }^{16}$, ustawę z dnia 31 maja 1996 r. o wyłączeniu niektórych ustaw o amnestii i abolicji wobec sprawców niektórych przestępstw, nie ściganych z przyczyn politycznych w latach 1944-198917, ustawę z dnia 7 maja 2009 r. o zadośćuczynieniu rodzinom ofiar zbiorowych wystąpień wolnościowych w latach 1956-198918.

Do najbardziej doniosłych należy oczywiście ustawa z 1991 r. o uznaniu za nieważne orzeczeń wydanych wobec osób represjonowanych za działalność na rzecz niepodległego bytu państwa polskiego, zwana również ustawą rehabilitacyjną. Objęła ona osoby najsilniej represjonowane, poddane sankcjom karnym. Wprowadziła przede wszystkim przepisy umożliwiające wnioskowanie o uznanie za nieważne orzeczeń karnych. Osobom objętym ustawą przyznano również możliwość dochodzenia roszczeń cywilnoprawnych o odszkodowanie i zadośćuczynienie. Ustawa z 1991 r. ogranicza możliwość uznania za nieważne orzeczeń jedynie do sytuacji, gdy czyn zarzucony lub przypisany był związany z działalnością na rzecz niepodległego bytu państwa polskiego albo gdy orzeczenie wydano z powodu takiej działalności oraz, gdy orzeczenie wydano za opór przeciwko kolektywizacji wsi i obowiązkowym dostawom, a także w sytuacji, gdy czyn został popełniony w celu uniknięcia represji w stosunku do siebie lub innej osoby ${ }^{19}$. Pomimo wprowadzenia wielu aktów prawnych normujących skutki w sferze prawa karnego dla obywateli, TK uznał jednak, że to właśnie $w$ tej sferze, tj. regulacjach prawnokarnych, szczególnie wyraziście rysuje się problem deficytu środków prawnych służących ochronie konstytucyjnych praw i wolności. W zakresie negatywnych skutków m.in. dekretów stanu wojennego względem stosunków pracy uchwalono przywołaną już ustawę z 1989 r. o przywróceniu praw pracowniczych.

Jednak uchwalone do tej pory akty prawne nie stanowią kompleksowego zespołu norm, który usuwałby negatywne dla obywateli skutki stanu wojennego. Nadzieję budził wyrok TK z 16 marca 2011 r. - długo wyczekiwany, bo wniosek do Trybunału został złożony przez rzecznika praw obywatelskich, symbolicznie zresztą, dnia 12 XII 2008 r. ${ }^{20}$ Zatem ponad 2 lata przyszło czekać na orzeczenie.

Rzecznik praw obywatelskich zwrócił się z wnioskiem o uznanie za niezgodne z konstytucją: dekretów o stanie wojennym, o postępowaniach szczególnych w sprawach o przestępstwa i wykroczenia w czasie obowiązywania stanu wojennego, o przekazaniu do właściwości sądów wojskowych spraw o niektóre

16 Dz. U. nr 34, poz. 149, ze zm.

17 Dz. U. nr 89, poz. 400.

18 Dz. U. nr 91, poz. 741.

19 O zakresie ustawy rehabilitacyjnej P. MIERZEJEWskı, Tzw. ustawa rehabilitacyjna na tle orzecznictwa Sądu Najwyższego, „Studia luridica” 1996, T. XXXI, s. 119 i n.

20 Pierwotnie Trybunał Konstytucyjny nie mógł zająć się dekretami stanu wojennego z przyczyn formalnych. Por. art. 35, a po ujednoliceniu art. 37 ustawy z dnia 29 kwietnia 1985 r. o Trybunale Konstytucyjnym, tekst jedn. z 1991 r., Dz. U. nr 109, poz. 470, ze zm. Kwestia stanu wojennego napotykała jednak trudności nie tylko prawne, lecz także polityczne; J. Kochanowskı, Posprzątać po stanie wojennym „Rzeczpospolita”, 12.12.2008. 
przestępstwa oraz o zmianie ustroju sądów wojskowych i wojskowych jednostek organizacyjnych Prokuratury PRL w czasie obowiązywania stanu wojennego, ustawy o szczególnej regulacji prawnej w okresie stanu wojennego i uchwały Rady Państwa w sprawie wprowadzenia stanu wojennego ze względu na bezpieczeństwo państwa. Jako podstawę powoływał przede wszystkim art. 7, art. 8 ust. 2 i 3, art. 31 ust. 1 Konstytucji RP. Podważał zatem działanie ówczesnych organów władzy jako działanie na podstawie i w granicach prawa. Wskazywał, że wolność człowieka podlega ochronie prawnej i jednocześnie odwoływał się do przepisu przewidującego bezpośrednie działanie przepisów konstytucji. Trybunał musiał w pierwszej kolejności rozstrzygnąć, w jakim stopniu Konstytucja RP z 1997 r. mogła stanowić wzorzec normatywny badania prawa sprzed okresu jej obowiązywania oraz czy możliwe jest orzekanie o konstytucyjności aktów, które utraciły moc obowiązywania. Istotne rozważania w tym zakresie przeprowadził w swoim stanowisku Prokurator Generalny wskazując, że wzorcem kontroli winna być Konstytucja PRL z 1952 r. Jak wiadomo, TK przychylił się do stanowiska RPO i przyjął za wzorzec kontroli art. 7 obecnie obowiązującej konstytucji, podając przy tym, że poddanie kontroli zaskarżonych a nieobowiązujących dekretów jest konieczne dla ochrony konstytucyjnych wolności i praw, ponieważ nowe ustawy nie w pełni usuwają skutki naruszeń wolności i praw.

Do szkód niepodlegających kompensacji na podstawie wymienionej ustawy rehabilitacyjnej rzecznik praw obywatelskich zaliczył uszczerbki związane z ograniczaniem wolności osobistej, ograniczaniem możliwości wyjazdów za granicę w celach prywatnych lub zawodowych, ograniczaniem swobody artystycznej oraz wolności słowa, które nie musiały wiązać się z propagandą polityczną czy wymierzaniem wyroków skazujących za czyny z rozdziału VI dekretu o stanie wojennym. Ponadto, utratę przez pokrzywdzonego dochodów na pokrycie utrzymania siebie i rodziny, a także uprawnienia do wcześniejszej emerytury, wskutek dyscyplinarnego zwolnienia z pracy za udział w strajku przeciwko wprowadzeniu w Polsce stanu wojennego, w sytuacji, gdy nie zapadło w związku z powyższym żadne orzeczenie karne, decyzja o zatrzymaniu czy internowaniu. Jest też zapewne cała sfera czynów nierównego traktowania czy dyskryminacji, które uległy wzmocnieniu w okresie stanu wojennego, a polegały na pomijaniu w awansie zawodowym, w dostępie do możliwości podnoszenia kwalifikacji, wymuszały pogorszenie warunków pracy czy korzystanie w dłuższym okresie wbrew woli pracowników z urlopów bezpłatnych.

Rzecznik praw obywatelskich wskazywał m.in. konkretne przykłady ciągle jeszcze negatywnego oddziaływania dekretów, pomimo ich uchylenia. Argumentował, że ocena legalności stanu wojennego może wpłynąć na ukształtowanie praw pokrzywdzonych, a ewentualny wyrok Trybunału Konstytucyjnego stwierdzający niekonstytucyjność kwestionowanych aktów normatywnych oraz podjęcie stosownych działań legislacyjnych przez ustawodawcę otworzyłoby pokrzywdzonym drogę do sądowego dochodzenia roszczeń od Skarbu Państwa za szkody 
poniesione w związku z wprowadzeniem w Polsce stanu wojennego. Rzecznik wskazywał możliwość zmian legislacyjnych, m.in. na gruncie prawa cywilnego oraz prawa zabezpieczenia społecznego. Podkreślał szczególnie dwa aspekty zaskarżonych regulacji: skutki prawnokarne dekretów i ich skutki w obszarze prawa pracy. Zdaniem RPO, stwierdzenie niekonstytucyjności dekretów jest czynnikiem niezbędnym dla usunięcia skutków pozostawania bez pracy $w$ wyniku rozwiązania stosunku pracy przez pracodawcę w czasie stanu wojennego, TK z kolei podkreślił, że ma świadomość naruszeń przepisów prawa pracy wynikających z przyczyn politycznych ${ }^{21}$, ale bierze pod uwagę fakt, że nie wszystkie naruszenia praw i wolności konstytucyjnych w czasie stanu wojennego stanowiły konsekwencję stosowania przepisów dekretów z 12 grudnia 1981 r. Działania organów władzy publicznej naruszające prawa i wolności konstytucyjne w czasie stanu wojennego były podejmowane na podstawie wielu innych ustaw. $Z$ drugiej strony analiza tych aktów prawnych, które zostały ustanowione w celu naprawienia krzywd i szkód wyrządzonych do 1989 r. przekonała TK, że regulacje te mają charakter selektywny. Usuwają skutki naruszeń wolności i praw konstytucyjnych w wielu wypadkach, lecz jednocześnie nie obejmują niektórych rodzajów naruszeń wolności i praw człowieka. TK uznał, że zasadniczym celem tych restytucyjnych aktów normatywnych było zapewnienie ochrony osobom poddanym niektórym formom represji w związku z prowadzoną przez nie działalnością opozycyjną. Poza zakresem ich działania pozostały, po pierwsze, niektóre inne formy represji politycznych, po drugie - wypadki naruszeń wolności i praw konstytucyjnych niemające charakteru represji za działalność polityczną, ale polegające na nielegitymowanej konstytucyjnie ingerencji w sferę najważniejszych wolności i praw ogółu obywateli, w szczególności ingerencji prawnokarnej, która dotykała również osoby niezaangażowane politycznie.

W sprawie - poza wnioskującym - dodatkowo zabierał głos Prezes Instytutu Pamięci Narodowej na wyraźne zapytanie TK. On również wskazywał prawo pracy jako jedną ze sfer naruszeń powodowanych dekretami. Szczególnie odniósł się do nieuregulowanej, jego zdaniem, kwestii majątku organizacji związkowych oraz pracowników związków zawodowych, którzy utracili miejsce pracy na podstawie przepisów zarządzenia nr 51, a do których, zdaniem Prezesa IPN, przepisy ustawy o przywróceniu praw pracowniczych nie mają zastosowania. Prezes IPN odniósł się też do następczych skutków w zakresie stosunków z ubezpieczeń społecznych. Dekret o stanie wojennym pozwalał na dyscyplinarne, zawinione przez pracownika wypowiedzenie umowy o pracę, a art. $42 \mathrm{w}$ związku $z$ art. 45 ust. 2 dekretu, w następstwie stosowania zasad dotyczących tymczasowego aresztowania przy wykonywaniu decyzji o internowaniu, mogły prowadzić do wygaśnięcia stosunku pracy z mocy ustawy. Prezes IPN podkreślił, że okresy

21 Trybunał Konstytucyjny przywołał pozycję: Stan wojenny w Polsce 1981-1983, red. A. Dudek, Warszawa 2003, w której wskazano przybliżone dane liczbowe. 
pozostawania bez pracy w związku z zastosowaniem tych przepisów wyznaczają do dziś zakres uprawnień w stosunkach z ubezpieczenia społecznego. W tym sensie przepisy te są nadal stosowane przed organami emerytalno-rentowymi oraz sądami pracy i ubezpieczeń społecznych, stanowiąc podstawę legalności aktów decydujących o długości okresów zatrudnienia oraz zaliczeniu okresów składkowych i nieskładkowych w rozumieniu obecnie obowiązujących przepisów ubezpieczeń społecznych. Trudno przesądzić, w jakim zakresie stanowisko IPN zostało przywołane w całości w uzasadnieniu. Zatem dla porządku dodać należy, że kwestie zwrotu majątku organizacjom związkowym i społecznym, poza przywoływanym przez IPN art. 45 ustawy o związkach zawodowych, ustawodawca podjął przede wszystkim w ustawie z dnia 25 października 1990 r. o zwrocie majątku utraconego przez związki zawodowe i organizacje społeczne w wyniku wprowadzenia stanu wojennego.

Trybunał Konstytucyjny uznał, że dekret z dnia 12 grudnia 1981 r. o stanie wojennym jest niezgodny z art. 7 Konstytucji RP w związku z art. 31 ust. 1 Konstytucji PRL z 1952 r. oraz z art. 15 ust. 1 Międzynarodowego Paktu Praw Obywatelskich i Politycznych, otwartego do podpisu w Nowym Jorku dnia 19 grudnia 1966 r. (Dz. U. 1977, nr 38, poz. 167) oraz, że dekret z dnia 12 grudnia 1981 r. o postępowaniach szczególnych w sprawach o przestępstwa i wykroczenia w czasie obowiązywania stanu wojennego (Dz. U. nr 29, poz. 156) jest niezgodny z art. 7 Konstytucji RP w związku z art. 31 ust. 1 Konstytucji PRL z 1952 r. oraz z art. 15 ust. 1 Międzynarodowego Paktu Praw Obywatelskich i Politycznych.

Trybunał Konstytucyjny - jak już wskazano - ustalił, że orzekanie w sprawie dekretów stanu wojennego było konieczne ze względu na ochronę konstytucyjnych wolności i praw. Jednocześnie zaznaczył, że skutki bezpośrednie jego orzeczenia są ograniczone, bo wielu praw i wolności nie da się przywrócić, a ich naruszeń wynagrodzić. Uznał jednak, że orzeczenie jest doniosłe dla ugruntowywania rządów prawa. Przysłuży się zachowaniu zasady zaufania obywateli do państwa. Zaznaczy gwarancyjną funkcję prawa i potwierdzi nadrzędną rolę konstytucyjnych przepisów, na wypadek podejmowania przez organy władzy publicznej działań bez podstawy prawnej i z naruszeniem zasad wprowadzania prawa w życie.

Mimo ograniczonych skutków bezpośrednich orzeczenia Trybunał odniósł się do jego skutków. Przypomniał, że każde jego orzeczenie stanowi podstawę do wznowienia postępowania, bo prawodawca konstytucyjny nie różnicuje skutków orzeczeń w zależności od tego, czy jest to niekonstytucyjność materialna, czy formalna. Dekret o stanie wojennym oraz dekret o postępowaniach szczególnych były uznawane przez organy władzy publicznej za obowiązujące akty normatywne i były przez nie stosowane. Wyrok Trybunału o niekonstytucyjności dekretów nie podważa wstecznie ich mocy obowiązującej w okresie, kiedy akty te obowiązywały i były stosowane. Otwiera natomiast drogę do zastosowania art. 190 ust. 4 Konstytucji RP i wznowienia postępowań, w których akty te zastosowano, przy czym bezpośrednią doniosłość swojego orzeczenia TK dostrzegał przede wszystkim w sferze prawa karnego. Jednak wznowienie postępowań karnych, 
w których stosowane były przepisy dekretów może nastąpić wyłącznie w takim zakresie, w jakim w konkretnej sprawie jest to niezbędne dla ochrony konstytucyjnych praw lub wolności. TK podkreślił, że organy stosujące prawo i podejmujące decyzje o wznowieniu postępowania, powinny w każdym wypadku ustalić, na czym polegało naruszenie tychże praw i wolności oraz czy wznowienie będzie stanowiło adekwatny i niezbędny $w$ danym wypadku środek sanujący owo naruszenie, a ponadto określić odpowiedni do tego zakres i charakter wznowienia, ograniczając je w szczególności do tych elementów postępowania lub orzeczeń w nim wydanych, które nie spełniały wspomnianego standardu konstytucyjnego.

Korzystanie z dobrodziejstwa wyroku TK w praktyce, jak zresztą zasugerował sam Trybunał, odbywa się w sposób co najmniej wyważony. W jednym z pierwszych orzeczeń po wyroku TK Sąd Apelacyjny w Warszawie postanowieniem z dnia 5 stycznia 2012 r. wskazał, że wyrok TK stwierdzający niezgodność z Konstytucją RP i Międzynarodowym Paktem Praw Obywatelskich i Politycznych dekretu o stanie wojennym i dekretu o postępowaniach szczególnych, odczytywany w kontekście art. 540 § 2 k.p.k. nie daje podstaw do wznowienia każdego postępowania, w którym Sąd powołał się na niektóre przepisy dekretów, ale upoważnia Sąd do rozważenia, czy zakwestionowane prawo stanowiło rzeczywistą podstawę skazania, a więc czy miało wpływ na sytuację procesową oskarżonego i pogorszyło tę sytuację w stosunku do tej, gdyby osądzono oskarżonego bez stosowania ustaw szczególnych, uznanych ostatecznie za niezgodne z obowiązującym porządkiem prawnym ${ }^{22}$. W innym wyroku SN wskazał, że wyrok TK z 16 marca 2011 r. nie może stać się podstawą wznowienia postępowania w sprawie, w której wyrok zapadł w zwyczajnym trybie (k.k. z 1969 r.) i nie znalazły w nim zastosowania dekrety, o których rozstrzygał $\mathrm{TK}^{23}$.

W sprawach pracowniczych i socjalnych szczególnie daleko idące skutki dotknęły osoby, które pozostawały z przyczyn politycznych bez pracy i bez ochrony socjalnej przez co nie nabyły prawa do świadczeń lub nabyły je w wymiarze zaniżonym, a wynikającym z krótszego okresu składkowego. Ustawa o przywróceniu praw pracowniczych w art. 11 ust. 2 wskazuje, że okresy pozostawania bez pracy po ustaniu stosunku pracy z osobą, która będąc pracownikiem (uspołecznionego zakładu pracy), z którą stosunek pracy został rozwiązany w jakikolwiek sposób

22 II AKo 164/2011, LexPolonica nr 3061409.

23 Postanowienie Sądu Najwyższego z dnia 13 grudnia 2011 r., IV KO 100/2011, LexPolonica nr 4449297, OSN z 2011 r., poz. 2363. Wśród późniejszych orzeczeń, które pojawiły się już po złożeniu artykułu, a zasługiwałyby na omówienie wskazać można już na gruncie roszczeń odszkodowawczych dochodzonych przed sądem cywilnym , lecz m.in. za skutki w sferze prawa pracy i ubezpieczeń społecznych np. wyrok SA w Katowicach z 5 lutego 2014 r., I Aca 1007/13, LEX 1437952, wyrok SA w Lublinie z 11 kwietnia 2013 r. LEX 1321988, wyrok SA w Łodzi z 10 października 2012 r., LEX 1237038. Innym razem w wyroku z 24 kwietnia 2014 r, LEX 1335757 SA w Warszawie stwierdza, że wyrok TK może wywoływać skutki tylko w sferze prawa karnego. W doktrynie zaś zob. B. ZDzieNNICKI, Badanie konstytucyjności stanu wojennego. Uwagi na tle wyroku Trybunału Konstytucyjnego z dnia 16 marca 2011 r., „Przegląd Prawa Konstytucyjnego” 2012, nr 3, s. 163, glosę do wyroku TK z 16 marca 2011 r., K 35/08 L. MażeWskiego, PiP nr 2/2013, s. 123. 
w związku z przekonaniami politycznymi, religijnymi pracownika, albo z jego przynależnością do związku zawodowego, prowadzeniem działalności związkowej lub samorządowej w okresie od sierpnia 1980 roku albo uczestniczeniem w działalności związkowej prowadzonej w sposób niezgodny z przepisami ustawy z dnia 8 października 1982 r. o związkach zawodowych ${ }^{24}$, wlicza się do stażu pracy, od którego zależą uprawnienia pracownicze, $w$ tym również z ubezpieczenia społecznego. Przepis ten miał zastosowanie również do osób, które nie skorzystały z prawa do ponownego nawiązania stosunku pracy. Przepis pojawił się przed reformą rewaloryzacyjną. Zgodnie z ówczesnymi przepisami prawa emerytalnego okres pozostawania bez pracy nie mógł więc zostać zaliczony odpowiednio do okresu składkowego, czy nieskładkowego. SN w swoich rozstrzygnięciach nie uwzględniał tej okoliczności prawnej. Kilkakrotnie (przed zmianą przepisów w 2013 r.) wskazywał, że okres pozostawania bez pracy, o którym mowa w art. 11 ust. 2 ustawy o przywróceniu praw pracowniczych osobom pozbawionym zatrudnienia za działalność związkową, samorządową, przekonania polityczne i religijne wlicza się do okresów nieskładkowych ${ }^{25}$. Wobec treści art. 7 ust. 4 ustawy o emeryturach i rentach z FUS stanowisko to akceptowała doktryna ${ }^{26}$. Na tle tych orzeczeń wyjątkiem stał się wyrok SA w Katowicach z 22 lutego 2007 r., gdzie przyjęto, że art. 11 ust. 2 przywoływanej ustawy daje podstawę do doliczenia okresu pozostawania bez pracy do okresów składkowych (do stażu pracy). Jednocześnie SA przyjął, że okres ten wlicza się jedynie na użytek ustalenia stażu. Ścisła interpretacja art. 11 ust. 2 nie pozwala na ustalenie podstawy wymiaru $z$ tamtego okresu, skoro ubezpieczony nie uzyskiwał wynagrodzenia.

Wątpliwości związane z zaliczaniem okresu pozostawania bez pracy w okresie 1981-1989 z przyczyn politycznych stały się również przedmiotem interpelacji poselskiej. Minister pracy i polityki społecznej wskazał w odpowiedzi na interpelację, że w związku z zaliczaniem okresu pozostawania bez pracy działaczy opozycji we wskazanym okresie odrębnie traktuje się osoby, które skorzystały z ustawy z 1989 r. o przywróceniu praw pracowniczych oraz osoby, które z tej ustawy nie skorzystały. W pierwszej sytuacji, okres pozostawania bez pracy uznany przez pracodawcę i zaliczony do uprawnień pracowniczych w trybie ustawy z $1989 \mathrm{r}$. o przywróceniu praw pracowniczych, w tym również do uprawnień z ubezpieczenia społecznego jest traktowany przez organ rentowy tak jak okres zatrudnienia, czyli jako okres składkowy. Okres ten nie podlega żadnym ograniczeniom co do długości okresu pozostawania bez pracy wskutek rozwiązania stosunku pracy z przyczyn określonych w art. 1 przywołanej ustawy. W drugim wypadku, osoby, które nie wykonywały pracy przed dniem 4 czerwca 1989 r. wskutek repre-

24 Tekst jedn., Dz. U. 1985, nr 54, poz. 277, ze zm.

25 Uchwała Sądu Najwyższego z dnia 6 lutego 2006 r., II UZP 13/2006, LexPolonica nr 1174866; wyrok Sądu Najwyższego z dnia 6 kwietnia 2006 r., II UK 180/2005, LexPolonica nr 1276158.

${ }^{26}$ K. Antonów, Komentarz do art. 7 ustawy o emeryturach i rentach z Funduszu Ubezpieczeń Społecznych, Warszawa 2009. 
sji politycznych i nie skorzystały z przepisów wymienionej ustawy mogą taki okres pozostawania bez pracy mieć zaliczony do stażu ubezpieczeniowego jako okres nieskładkowy na podstawie art. 7 pkt 4 ustawy o emeryturach i rentach z FUS, ale nie więcej niż 5 lat $^{27}$.

Stanowisko traktujące okres pozostawania bez pracy z przyczyn politycznych jako okres składkowy nie spotkało się z aprobatą SN w kolejnych orzeczeniach zapadłych już po wyroku TK z 16 marca 2011 r., który w ocenie SN zapewne niczego nowego nie wnosił do tej kategorii spraw, skoro SN nawet się do niego nie odniós ${ }^{28}$. SN przywołał art. 7 ust. 4 ustawy o emeryturach i rentach z FUS i potwierdził tezę zapadłą w wyroku z dnia 6 kwietnia 2006 r.

I początkowo wydawać się mogło, że wyrok Trybunału Konstytucyjnego nie spełnił pokładanych w nim nadziei. Zdaniem wnioskującego J. Kochanowskiego, rzecznika praw obywatelskich, wyrok wraz z następującymi po nim zmianami legislacyjnymi mógłby stanowić skuteczny środek w szczególności do przywrócenia ochrony takich praw jak ochrona prawa własności i dziedziczenia, prawa do sądu, czy właśnie prawa do zabezpieczenia społecznego. Został tymczasem oceniony w swoich skutkach przede wszystkim jako orzeczenie mające charakter symboliczny i to nie upływ czasu jest winowajcą, jak sugerowano. Ustawodawca podejmował bowiem kilka lat temu kwestie rekompensat strat wyrządzonych w okresie dużo odleglejszym (w okresie wojennym i powojennym). Dla przykładu, na skutek wykonania wyroku Europejski Trybunał Praw Człowieka z dnia 22 czerwca 2004 r. w sprawie ze skargi p. Broniewskiego oraz wyroku TK z dnia 15 grudnia 2004 r., którym orzekł o niezgodności z konstytucją niektórych przepisów ustawy z dnia 12 grudnia 2003 r. o zaliczaniu na poczet ceny sprzedaży albo opłat z tytułu użytkowania wieczystego nieruchomości Skarbu Państwa wartości nieruchomości pozostawionych poza obecnymi granicami państwa polskiego uchwalił ustawę z dnia 8 lipca 2005 r. o realizacji prawa do rekompensaty z tytułu pozostawienia nieruchomości poza obecnymi granicami Rzeczypospolitej Polskiej ${ }^{29}$. W sprawie dekretów już sam TK wyznaczył ostrożnie ścieżkę interpretacyjną swojego orzeczenia. Chociaż wskazał potencjalną możliwość wznowienia postępowania, podkreślał precyzyjne warunki owego wznowienia i znaczenie wyroku przede wszystkim z punktu widzenia zaufania obywateli do prawa. Czym jest jednak formalna obrona zasad konstytucyjnych, jeśli nie zostaną one urzeczywistnione?

${ }^{27}$ Już po oddaniu artykułu do publikacji do Sejmu wpłynął senacki projekt ustawy o zmianie ustawy o emeryturach i rentach z Funduszu Ubezpieczeń Społecznych druk nr 1270 przewidujący uchylenie art. 7 ust. 4 i powołujący w art. 6 ust. 2 pkt. $6 a$ traktujący okresy niewykonywania pracy w okresie po dniu 31 grudnia 1956 r. a przed dniem 4 czerwca 1989 r. na skutek represji politycznych jako okresy składkowe. 20 grudnia 2013 r. Prezydent podpisał ustawę z 22 listopada 2013 r. o zmianie ustawy o emeryturach I rentach z FUS, Dz.U. 2014 , poz. 1734. Zmianie przy tej okazji uległy również art. 57 ust. 1 pkt. 3,117 ust. 4 i 174 ust. 2 pkt. 3. Ustawa przewidziała również możliwość ponownego ustalenia świadczenia w związku z tą zmianą.

${ }^{28}$ Wyrok Sądu Najwyższego z dnia 5 lipca 2011 r., I UK 1/2011, LexPolonica nr 2785765, wyrok Sądu Najwyższego z dnia 15 lutego 2012 r., I UK 239/11, OSNP 2013/1-2/19.

${ }^{29}$ Dz. U. nr 169, poz. 1418, ze zm. 
Trybunał Konstytucyjny nie mógł, co prawda, orzec o wpływie swojego orzeczenia na stosowanie innych przepisów prawa, nieobjętych wnioskiem. Jest związany granicami wniosku, odgrywa jedynie rolę ustawodawcy negatywnego w omawianym wypadku. Jeśli jednak dekrety stanu wojennego zostały uznane w całości za sprzeczne z Konstytucją RP i Międzynarodowym Paktem Praw Obywatelskich i Politycznych, należało zweryfikować dotychczasowe regulacje restytucyjne względem krzywd i szkód wyrządzonych w okresie stanu wojennego oraz rozważyć potrzebę ustawy rekompensującej straty inne niż wskazane $w$ dotychczasowych ustawach restytuujących prawa naruszone dekretami. Wyrok Trybunału Konstytucyjnego zmienił otoczenie prawne i kontekst obowiązujących przepisów o restytucyjnym charakterze. Z satysfakcją zatem przyjąć należy zmianę w ustawie o emeryturach i rentach z FUS, w wyniku której okresy niewykonywania pracy w okresie po dniu 31 grudnia 1956 r. a przed dniem 4 czerwca 1989 r. na skutek represji politycznych uznane zostały za okresy składkowe. 